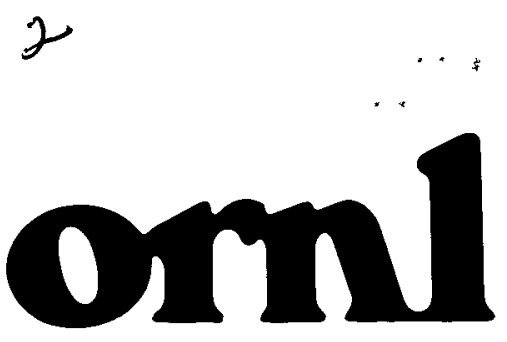

\section{OAK RIDGE NATIONAL LABORATORY}

MARTIN MARIETHA

\section{Rec6isger by 097 \\ MAY $O \& 1986$}

ORNL/TM-9958

\title{
The Reduction of Plutonium(IV) Using Photochemically Generated Uranium(IV)
}

\author{
L. M. Toth \\ L. K. Felker
}

\section{DO NOT MICROFILII COVER}

OPERATED BY

MARTIN MARIETTA ENERGY SYSTEMS, INC.

FOR THE UNITEO STATES

DEPARTMENT OF ENERGY 


\section{DISCLAIMER}

This report was prepared as an account of work sponsored by an agency of the United States Government. Neither the United States Government nor any agency Thereof, nor any of their employees, makes any warranty, express or implied, or assumes any legal liability or responsibility for the accuracy, completeness, or usefulness of any information, apparatus, product, or process disclosed, or represents that its use would not infringe privately owned rights. Reference herein to any specific commercial product, process, or service by trade name, trademark, manufacturer, or otherwise does not necessarily constitute or imply its endorsement, recommendation, or favoring by the United States Government or any agency thereof. The views and opinions of authors expressed herein do not necessarily state or reflect those of the United States Government or any agency thereof. 


\section{DISCLAIMER}

Portions of this document may be illegible in electronic image products. Images are produced from the best available original document. 


\section{Printed in the United States of America. Available from Natıonal Technical Information Service \\ U.S. Department of Commerce \\ 5285 Port Royal Road, Sprıngfield, Virginia 22161}

NTIS price codes-Printed Copy: A03 Microfiche A01

This report was prepared as an account of work sponsored by an agency of the United States Government Neither the United States Government nor any agency thereof, nor any of their employees, makes any warranty, express or implied, or assumes any legal liablity or responsibility for the accuracy, completeness, or usefulness of any information, apparatus, product, or process disclosed, or represents that its use would not infringe privately owned rights Reference herein to any specific commercial product, process, or service by trade name, trademark, manufacturer, or otherwise, does not necessarily constitute or imply its endorsement, recommendation, or favoring by the United States Government or any agency thereof The views and opinions of authors expressed herein do not necessarily state or reflect those of the United States Government or any agency thereof

\section{DO NOT MICROFILM COVER}


L. M. Toth

L. K. Felker

\title{
DISCLAIMER
}

This report was prepared as an account of work sponsored by an agency of the United States Government Netther the United States Government nor any agency thereof, nor any of their employees, makes any warranty, express or implied, or assumes any legal liability or responsibility for the accuracy, completeness, or usefulness of any information, apparatus, product, or process disclosed, or represents that its use would not infringe privately owned rights Reference herein to any specific commercial product, process, or service by trade name, trademark, manufacturer, or otherwise does not necessarily constitute or imply its endorsement, recommendation, or favoring by the United States Government or any agency thereof The views and opınions of authors expressed herein do not necessarıly state or reflect those of the United States Government or any agency thereof

\author{
Prepared by \\ OAK RIDGE NATIONAL LABORATORY \\ Oak Ridge, Tennessee 37831 \\ operated by \\ MARTIN MARIETTA ENERGY SYSTEMS, INC. \\ for the \\ U.S. DEPARTMENT OF ENERGY \\ under Contract No. DE-ACO5-840R2 1400
}


CONTENTS

Page

ABSTRACT . . . . . . . . . . . . . . . . . . 1

1. INTRODUCTION . . . . . . . . . . . . . . . . 1

2. EXPERTMENTAL METHODS .................. 3

$2.1 \mathrm{UO}_{2}{ }^{2+}$ PHOTOLYSIS SYSTEM . . . . . . . . . . . 4

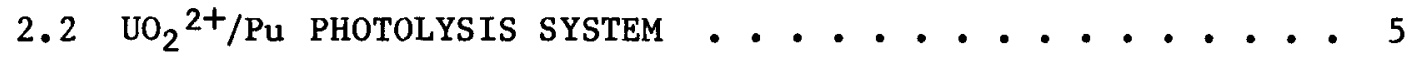

2.3 MATERIALS AND PREPARATIONS . . . . . . . . . . 10

2.4 ACTINOMETRY . . . . . . . . . . . . . . 11

2.5 SPECTROPHOTOMETRY . . . . . . . . . . . . 12

2.6 COUNTING TEChNIQUES . . . . . . . . . . . 14

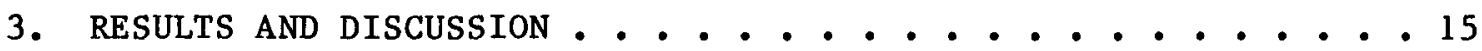

3.1 PHOTOLYSIS OF URANYL ION ............ 16

3.2 URANIUM/PLUTONIUM PHOTOLYSIS . . . . . . . . . 19

4. CONCLUSIONS • . . . . . . . . . . . . . . . 31

5. REFERENCES . . . . . . . . . . . . . . . . 32 


\begin{abstract}
The reduction of $\mathrm{Pu}(\mathrm{IV})$ using photochemically generated U(IV) has been evaluated as a procedure for possible inclusion in the Savannah River Plant's nuclear fuel reprocessing facility. The "Purex 2nd Uranium Cycle" with feed conditions of $400 \mathrm{~g} / \mathrm{L} \mathrm{U}, 1 \mathrm{M} \mathrm{HNO}_{3}$, and $10^{-8}$ to $10^{-6} \mathrm{M} \mathrm{Pu}$ was identified previously as the most promising stage for application of a photochemical method. Laboratory tests were conducted under similar conditions to determine if the plutonium could be successfully reduced and separated in a two-phase flowing system. The laboratory scale tests, which used primarily a $0.01 \mathrm{M}$ butanol/0.01 M hydrazine reductant combination, demonstrated that reductive stripping of $\mathrm{Pu}(\mathrm{IV})$ using photochemically generated $\mathrm{U}(\mathrm{IV})$ is a practical method for removing plutonium from the organic phase. The kinetics of the reductive stripping procedure were found to be determined by the mixing rates of the organic and aqueous phases in this simple laboratory-scale system.
\end{abstract}

\title{
1. INTRODUCTION
}

The possibility of using photochemical techniques in nuclear fuel reprocessing operations has been an attractive idea for at least 15 years. The impetus for this application comes largely from a compelling need to reduce the amount of waste solution generated during reprocessing. A photochemical process could eliminate customary chemical redox agents, such as ferrous sulfamate, that contribute substantially to the waste.

During the past decade, we have accumulated much information on the fundamental photochemistry of uranium, plutonium, and neptunium in aqueous acid solutions; $;^{-4}$ also, patents for several attractive photochemical 
processes have been filed or granted. 5-7 The most technically promising of these processes involves the separation of neptunium, using nitrite ion generated by the photochemical reduction of some of the $\mathrm{HNO}_{3}$ solvent. We have examined this chemistry to some extent, and the results are described in an earlier report on photochemical applications to the Savannah River Plant (SRP) reprocessing facility. ${ }^{8}$

The more immediate requirement appears to be that of plutonium separation in the Purex 2nd Uranium Cycle feed, as described in ref. 8. A research effort was therefore initiated to determine the feasibility of incorporating a photochemical redox process into the SRP plutonium separation scheme and also to determine the optimum conditions for the use of the process. The best reductant for $\mathrm{Pu}^{4+}$ for these purposes is $\mathrm{U}^{4+}$, which is generated by the photochemical reduction of $\mathrm{UO}_{2}{ }^{2+}$ using a suitably chosen secondary* reductant. The advantage gained by this two-step process.

$$
\begin{aligned}
\mathrm{UO}_{2}{ }^{2+}+\mathrm{R} & =\mathrm{U}^{4+}+\mathrm{R}^{\prime}, \\
2 \mathrm{Pu}^{4+}+\mathrm{U}^{4+}+2 \mathrm{H}_{2} \mathrm{O} & =2 \mathrm{Pu}^{3+}+\mathrm{UO}_{2}{ }^{2+}+4 \mathrm{H}^{+},
\end{aligned}
$$

is that uranyl ion is reduced with a higher quantum efficiency in nitric acid solutions than is $\mathrm{Pu}^{4+}$.

*The secondary reductant, designated as "R" in Eq. (1), is defined here as that which is effective in photochemically reducing $\mathrm{UO}_{2}{ }^{2+}$ to $\mathrm{U}^{4+}$, the primary reductant which, in turn, reduces the $\mathrm{Pu}^{4+}$ to $\mathrm{Pu}^{3+}$. The designation $U(V I)$ and $U(I V)$ will be used to denote oxidation states with no definition of the species. The ions involved, however, will be indicated as $\mathrm{UO}_{2}{ }^{2+}$ and $\mathrm{U}^{4+}$, respectively. 
Although the interaction of 11 ght with uranyl ion has been extensively studied over the past several decades, relatively little has been done regarding direct photochemical reduction of uranyl ion in nitric acid solutions. We have sought to remedy this omission by measuring the formation of $\mathrm{U}^{4+}$ from the photochemical reduction of $\mathrm{UO}_{2}{ }^{2+}$ in $1 \mathrm{M} \mathrm{HNO}_{3}$. These data were necessary in order to determine the best conditions (i.e., identity and concentration of secondary reductant) for $\mathrm{U}^{4+}$ production that were compatible with the SRP reprocessing system.

This report describes our preliminary studies of uranyl nitrate photochemistry in $1 \underline{\mathrm{M}} \mathrm{HNO}_{3}$. Upon selection of the secondary reductant, $\mathrm{Pu}^{4+}$ was added and the combined solution was tested for plutonium reduction in both one-phase (aqueous) and two-phase (aqueous/organic) operations. Although the experiments were conducted in a small-scale laboratory apparatus, the results provide much information that is required for testing on a larger scale.

The analytical determination of actinide concentrations involved both scintillation counting in the aqueous phase combined with absorption spectrophotometry (when the concentrations were high enough) and scintillation counting alone in the organic phase. The PERALS 9,10 scintillation counting technique allowed us to obtain meaningful data at the low concentrations reported here.

\section{EXPERIMENTAL METHODS}

The experimental approach was progressive in nature, beginning with the determination of the best uranyl photolysis conditions. Next, $\mathrm{Pu}^{4+}$, in relatively high concentration, was added to the one-phase aqueous 
system, and the reduction of the $\mathrm{Pu}^{4+}$ to $\mathrm{Pu}^{3+}$ was monitored spectrophotometrically. This reduction was then followed by a two-phase (TBP, n-dodecane organic/ $/ \mathrm{HNO}_{3}$ aqueous) flow system where the aqueous phase was photolyzed after prior equilibration of the various constituents. After the system had become operational at relatively high $\left[\mathrm{Pu}^{4+}\right]$, the concentration was decreased in subsequent experiments until the detection limits of the spectrophotometer were reached and the need for a more sensitive detection system arose. Two alpha scintillation counting procedures were used to provide more quantitative results for the very low $\left[\mathrm{Pu}^{4+}\right]$ in the presence of large amounts, $1.0 \mathrm{M}$, of uranyl ion. The various steps in this procedure are described in the following paragraphs.

\section{$2.1 \mathrm{UO}_{2}{ }^{2+}$ PHOTOLYSIS SYSTEM}

The initial uranium photoreduction tests were made using a Scoeffel $1000^{-W}$ mercury-xenon vapor arc lamp. The light output of the lamp was filtered through a combination of Pyrex and Plexiglas plates and focused on a spectrophotometer cell fitted into a Cary $14 \mathrm{H}$ spectrophotometer. The use of the filters was necessary to remove the ultraviolet (uv) and the high-energy-visible light which would photolyze the nitrate ion and thereby produce undesirable side reactions. The Pyrex-Plexiglas combination gave a sharp cutoff at $350 \mathrm{~nm}$. A polycarbonate filter that passed light of a $>400-\mathrm{nm}$ wavelength was also used to test the effect of wavelength on the uranyl photolysis. These filters proved to be more satisfactory than commercially available Corning glass filters because they had cutoff bands at preferred wavelengths and/or gave sharper cutoffs. It was necessary to air-cool the plastic filters to prevent 
them from melting. The distance from the lamp to the cell was approximately $30 \mathrm{~cm}$. The photochemical cell (see Fig. 1) was fabricated from silica and consisted of a $1.5-\mathrm{cm}-\mathrm{diam}$ by 5 -cm-pathlength body fitted with a magnetic stir-bar pump and water jacket. The total volume of the cell and stirring leg was $17 \mathrm{~mL}$. The temperature for each of these tests was $25^{\circ} \mathrm{C}$, except where noted otherwise. In a typical experiment, the uranium solution was added to the ce11 and a spectrum was obtained. The reductants were then added, and the arc lamp was used to photolyze the solution for a measured time while the growth of the $\mathrm{U}^{4+}$ band was monitored with the spectrophotometer. This allowed for determination of the $\mathrm{U}^{4+}$ production rates. Several tests were performed with this system to determine the concentrations and types of reductants that would provide for maximum $\mathrm{U}^{4+}$ production.

\section{$2.2 \mathrm{UO}_{2}{ }^{2+} / \mathrm{Pu}$ PHOTOLYSIS SYSTEM}

The photoreduction of samples containing plutonium required the use of a modified glove box-spectrophotometer arrangement, as shown in Fig. 2 . An appendage attached to the glove box allowed the light from the spectrophotometer to pass through silica windows on the appendage. Since the $\mathrm{UO}_{2}{ }^{2+} / \mathrm{Pu}^{4+}$ photolysis would incorporate a two-phase extraction system, a new cell configuration (see Fig. 3) was designed and then fabricated from Pyrex. Again, the spectrophotometer cell had a 5-cm pathlength; however, it now had a $2.0-\mathrm{cm}-\mathrm{diam}$ body.

Above the cell was a water-jacketed chamber $(2.0 \times 15 \mathrm{~cm})$ for the organic phase which provided an organic/aqueous ratio of $1: 1$. A similar configuration with a $4.5-\times 15-\mathrm{cm}$ chamber for the organic phase was fabricated to provide higher organic/aqueous ratios $(4: 1$ to $5: 1)$. The 


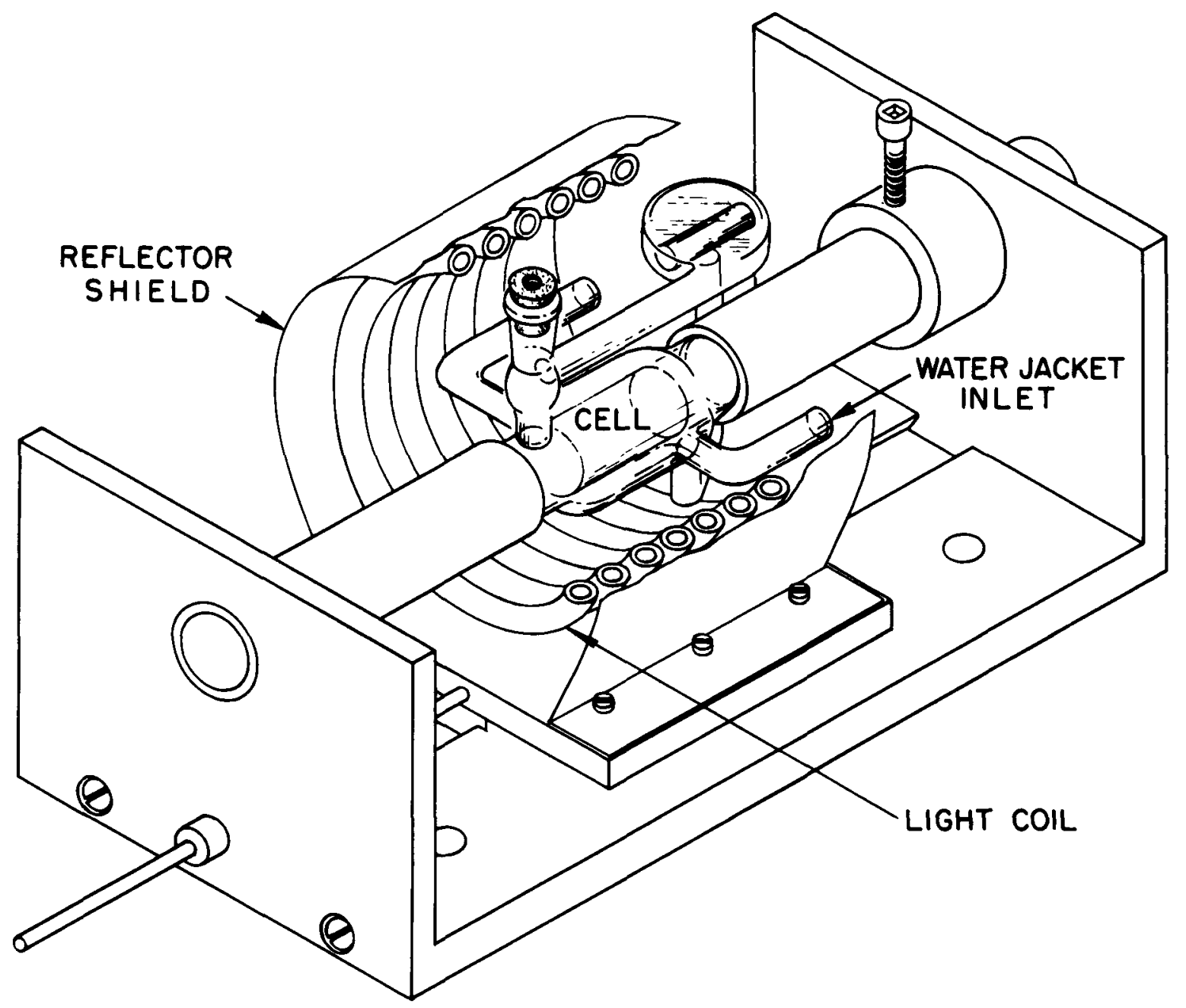

Fig. 1. Compact photochemical cell that permits in-line absorption spectrophotometric measurements. 
ORNL PHOT0-5149-79

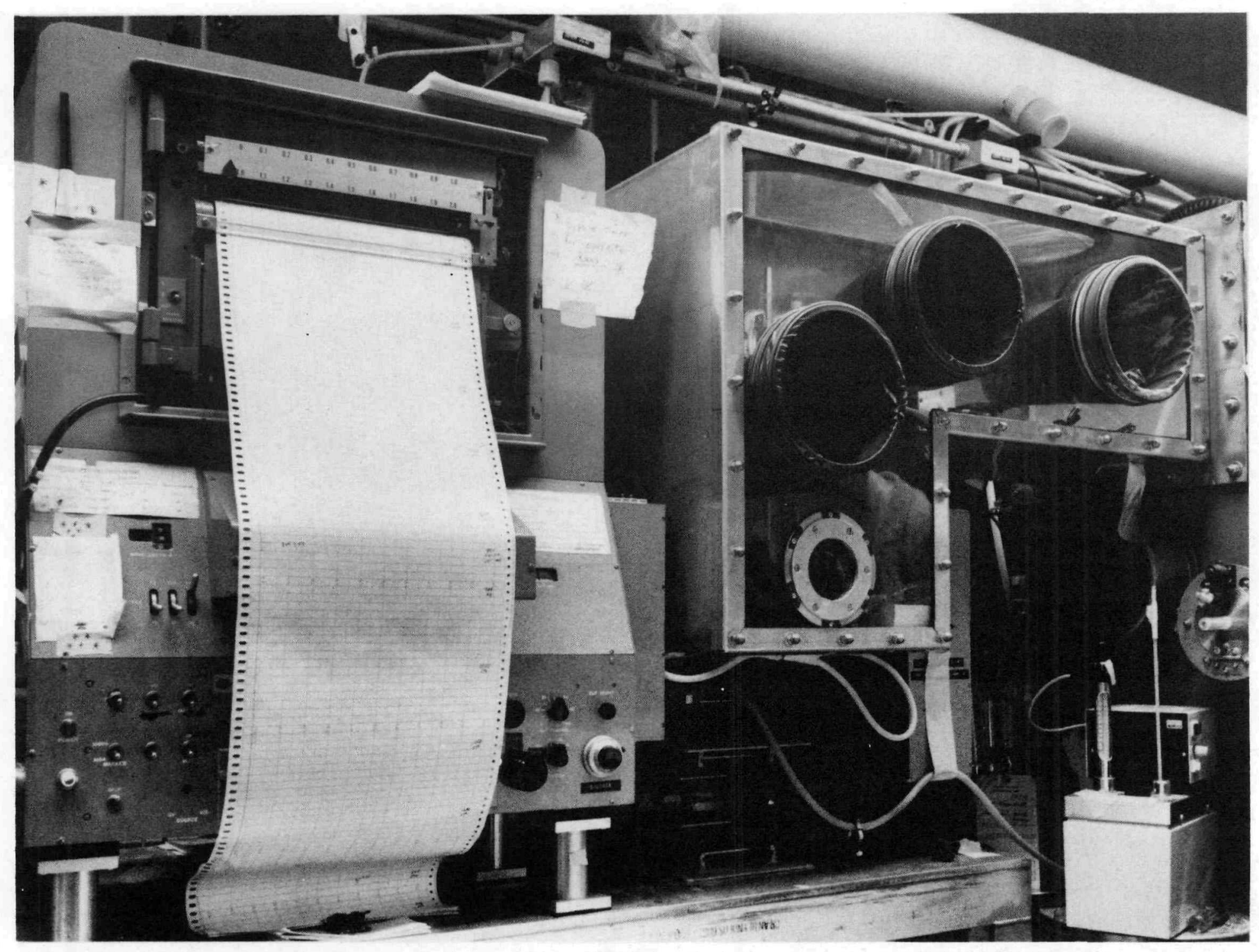

Fig. 2. Photograph of glove-box appendage that permits absorption spectral measurements on alpha-active materials without contaminating the glove box. 
ORNL PHOT0-8747-85

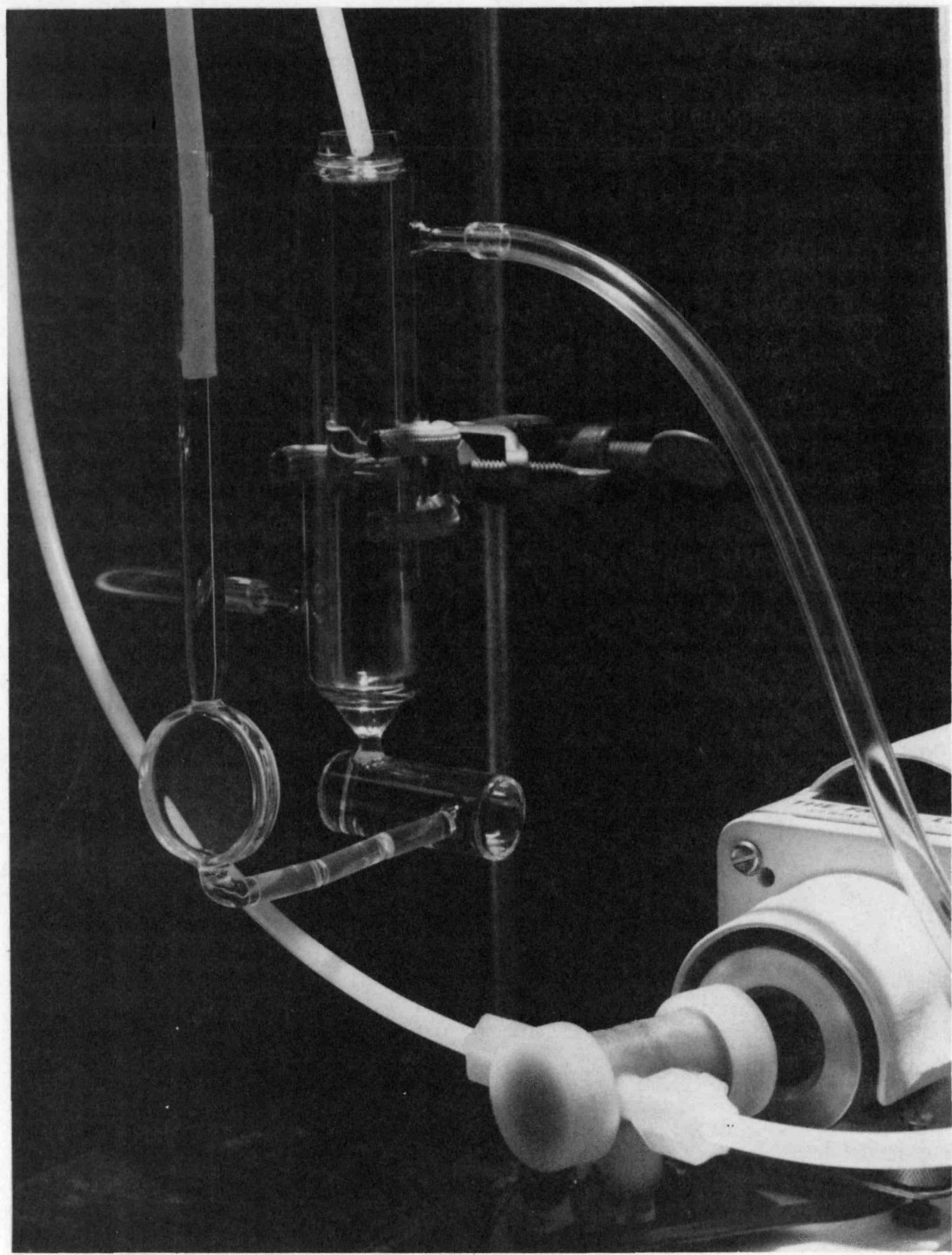

Fig. 3. Photograph of two-phase extraction system. The organic phase was confined to the water-jacketed column above the $5-\mathrm{cm}$ pathlength spectrophotometric cell. The photolysis compartment is to the right. 
photolysis chamber ( $4-\mathrm{cm}$ diam $\times 1-\mathrm{cm}$ pathlength) was used to provide a large-area window for the light. The short pathlength of the chamber was necessary to keep volumes at a minimum, although the design sacrificed some light absorption in the more-dilute uranyl nitrate solutions. The aqueous phase was circulated through the system with an FMI piston pump at $22 \mathrm{~mL} / \mathrm{min}$. The aqueous phase was drawn from the top of the photolysis chamber and discharged at the top of the organic phase, where it dispersed and fell through the organic solution. The pump discharge at the top of the organic phase provided moderate mixing in the organic phase; but in the higher organic/aqueous ratios, the organic phase was stirred occasionally with a glass rod to ensure complete mixing. In spite of the rather gentle agitation, we were sometimes troubled with the appearance of the organic phase in the spectrophotometric cell which caused very noisy aqueous solution spectra.

The same mercury-vapor arc lamp was used in this series of photoreductions. The Pyrex and Plexiglas filters that remove the high-energyvisible and uv light were mounted on the outside of the glove-box appendage. The output of the lamp passed first through the Pyrex and Plexiglas filters, then through the silica windows of the glove-box appendage, and finally into the photolysis chamber containing the aqueous $\mathrm{UO}_{2}{ }^{2+} / \mathrm{Pu}^{4+}$ nitrate solution. Aluminum foll was used to shield the rest of the apparatus from the light. The production of $\mathrm{U}^{4+}$ or the reduction of $\mathrm{Pu}^{4+}$ to $\mathrm{Pu}^{3+}$ was monitored on a Cary $14 \mathrm{H}$ spectrophotometer or sampled for alpha scintillation counting.

The quantum yield (QY) for Pu(III) production was determined for the reference solution (run 60, described in Sect. 3) by measuring the amount of time required to reach nearly complete (i.e., 95\%) reduction of the 
$\mathrm{Pu}(\mathrm{IV})$ to $\mathrm{Pu}(\mathrm{III})$ as determined by monttoring the absorbance in the aqueous phase. No dark reduction of $\mathrm{Pu}(\mathrm{IV})$ was ever observed; thus, the only error in this determination would be caused by a delay in the reaction of the reduced uranium (principally $\mathrm{U}^{4+}$, but see Sect. 3) with the $\mathrm{Pu}^{4+}$ as a result of slow kinetics or slow mixing of the solutions. Therefore, any error in the $Q Y$ value measured by this approach would be on the low side of the true value. We believe that the QY value for the reference solution is accurate because it corresponds to the value found in the single-phase solution; however, the values for solutions containing lower concentrations of butanol/hydrazine $\left(\mathrm{BuOH} / \mathrm{N}_{2} \mathrm{H}_{4}\right)$ reductant are apparent1y lower as a result of the slow rate of solution mixing by the FMI pump. Obtaining more accurate QY values for the other solutions would have required interruption of the photolysis to allow for mixing, a procedure that would have unduly complicated the photolysis procedure.

\subsection{MATERIALS AND PREPARATIONS}

All chemicals used in this study were analytical-grade reagents. The uranium, as uranium dinitrate oxide hexahydrate (IUPAC* name for urany1 nitrate hexahydrate), and the hydroxylamine nitrate, as a $24 \%$ solution, were obtained from Alfa Products. The tributyl phosphate, $\underline{n}$-dodecane, and hydrazine were obtained from Fisher Scientific. The phenylhydrazine was from Eastman Chemicals Products, Inc. The plutonium was obtained on-site as a $0.1 \mathrm{M}$ plutonfum(IV) nitrate solution which had been purifled by standard ion-exchange techniques. Analytical-grade nitric acid and ultrapure water were used in the preparation of all solutions.

\footnotetext{
*International Union of Pure and Applied Chemistry.
} 
The 30\% TBP-NDD solution was pre-equilibrated with $1.0 \underline{\mathrm{M}} \mathrm{HNO}_{3}$ before use. A11 the solution components were added to the cell, except for the reductants which were introduced just before the photolysis to prevent any photolysis from stray room light. The concentrations reported for the solutions in the two-phase system are those in the aqueous phase prior to the extraction of uranium and plutonium into the organic phase. The individual concentrations of the species in the different phases will be noted where necessary.

\subsection{ACTINOMETRY}

A measure of the light absorption by the solution was needed in order to determine quantum efficiencies (or yields: $Q Y=$ mol of product formed/mol of light absorbed. The $\mathrm{UO}_{2} \mathrm{SO}_{4}$ solution with ethanol (EtOH) reductant was ideal for our study, since the amount of light absorbed by the uranyl ion was the quantity in question. The key difference between the sulfate and the nitrate systems was the stability of the $\mathrm{U}^{4+}$ product, $\mathrm{QY}=0.5$, in the former, making it ideal for actinometry. A solution containing $1.25 \mathrm{M} \mathrm{UO}_{2} \mathrm{SO}_{4}, 5.0 \mathrm{M} \mathrm{H}_{2} \mathrm{SO}_{4}$, and $1.0 \underline{\mathrm{M}}$ ethanol was used as the actinometer. In the two-phase system, the amount of absorbed light was determined by the photolysis of similar solutions of $0.14,0.07$, and $0.035 \underline{\mathrm{M} \mathrm{UO}} \mathrm{SO}_{4}$ which were representative of the uranyl concentrations in the aqueous raffinate after extraction. Typically, for $0.035 \underline{M}$ uranyl solutions, the absorbed wattage in the photolysis ce11 using the PyrexPlexiglas filter was $0.618 \mathrm{~W}$, while that using the polycarbonate filter was $0.362 \mathrm{~W}$.

\footnotetext{
*This value has been reported ${ }^{l} l$ to be as high as 0.6 , but for the sake of this discussion, the theoretical value of 0.5 is sufficient and does not alter the conclusions that follow in the discussion of results.
} 


\subsection{SPECTROPHOTOMETRY}

As stated above, the spectrophotometric analysis was performed with a Cary 14H system, which has an open sample and reference compartment $(42 \times 40 \times 30 \mathrm{~cm})$. The appendage from the glove box was designed to fit into this compartment (see Fig. 2), thus allowing spectrophotometric measurements to be made of solutions inside the glove box. All of the measurements were recorded on a strip-chart recorder. Good spectra were obtained during the uranyl-plutonium photolysis when the plutonium concentration was $>1 \times 10^{-3} \underline{\mathrm{M}}$. When the concentration was $<1 \times 10^{-3} \underline{\mathrm{M}}$, a more sensitive recorder slide-wire ( 0 to 0.2 abs vs the standard 0 to 2.0 abs) was utilized. The 0 - to 0.2 -abs slide-wire gave good results, but the noise level of the recorder was significantly increased. For plutonium concentrations $<1 \times 10^{-4} \mathrm{M}$, the intensity of the spectrum was too small to measure accurately, thus mandating counting techniques.

The photolysis of $\mathrm{UO}_{2}{ }^{2+}$ was monitored spectrophotometrically by following the growth of the $\mathrm{U}^{4+}$ absorption band at either 545 or $648 \mathrm{~nm}$. Representative spectra of the uranium species in $1.3 \mathrm{M} \mathrm{HNO}_{3}$ are shown in Fig. 4. (This figure was adapted from an earlier report.12 Under the experimental conditions used in this study, the uranyl peak at $414 \mathrm{~nm}$ was typically very intense and therefore too far off scale to measure; these conditions were necessary to permit the accurate measurement of the weaker $\mathrm{U}^{4+}$ product spectrum. The weak uranyl band at $485 \mathrm{~nm}$ with a molar absorptivity of $0.505 \mathrm{M}^{-1} \mathrm{~cm}^{-1}$ was the only band available under these conditions. 


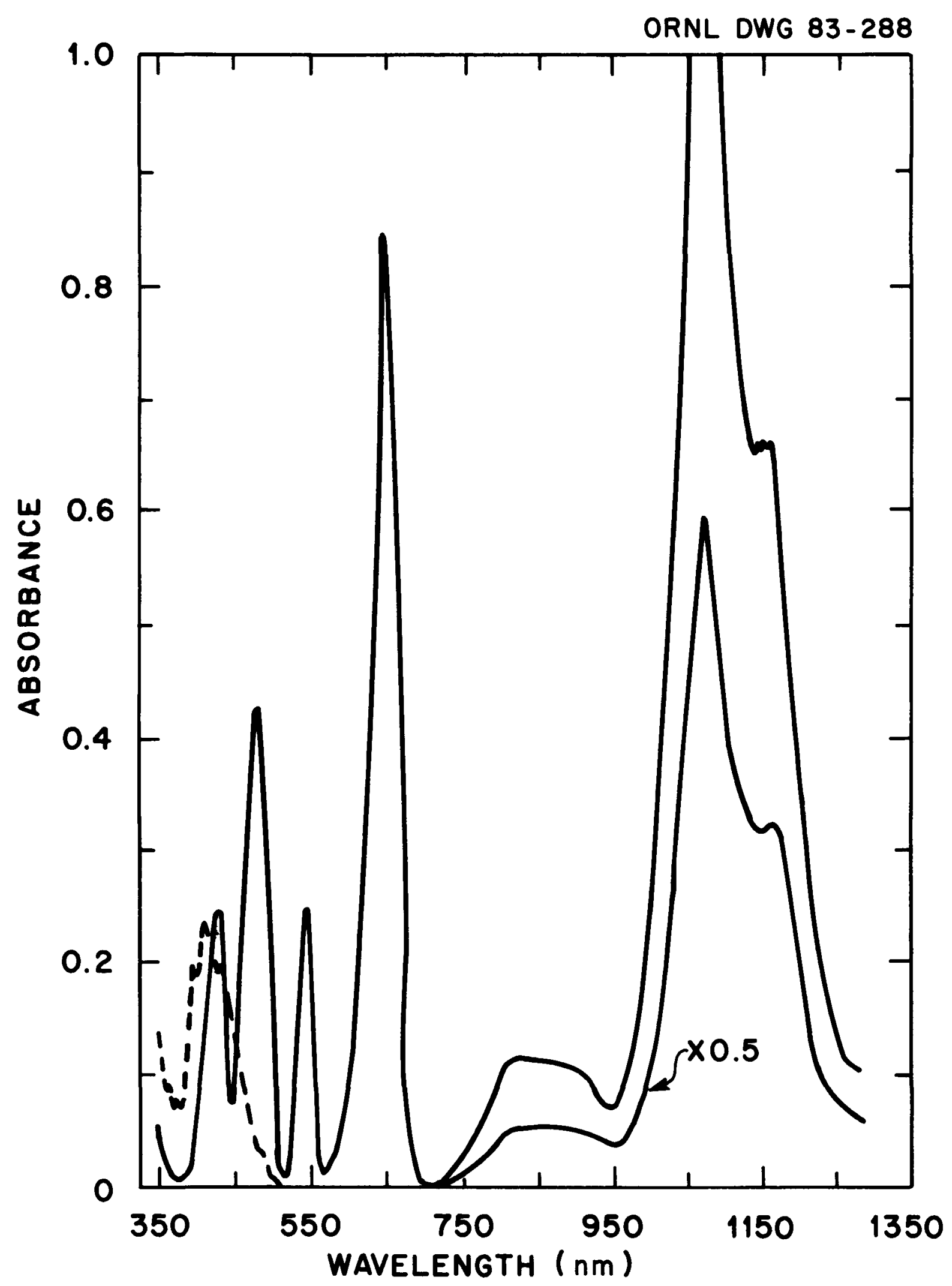

Fig. 4. Absorption spectral2 of $6.4 \mathrm{~g} / \mathrm{L}$ uranyl nitrate (dashed line) and $6.4 \mathrm{~g} / \mathrm{L} \mathrm{U} \mathrm{U}^{4+}$ nitrate in $1.3 \mathrm{M} \mathrm{HNO} 3$ (solid lines). 


\subsection{COUNTING TECHNIQUES}

Counting techniques were utilized to determine the distribution of plutonium between organic and aqueous phases in solutions with plutonium concentrations $<10^{-4}$ M. An LKB-Wallac RackBeta counter was used for alpha scintillation counting. Results were good for higher concentrations where plutonium gave the dominant signal, but poor resolution of the uranium and plutonium bands at plutonium concentrations $<1 \times 10^{-4} \underline{\mathrm{M}}$ precluded the usage of this technique. An improved scintillation procedure, Photon-Electron Rejecting Alpha Liquid Scintillation (PERALS)9,10 developed by McDoweIl and Case of ORNL, was then selected. This method permitted discrimination between the alpha and beta-gamma energies while providing the resolution to separate the uranium and plutonium alpha scintillation bands, thus giving quantitative results for concentrations as low as $10^{-7}$ to $10^{-8} \mathrm{M}$ plutonium in $0.1 \mathrm{M}$ uranium. With this method, analyses of samples were accomplished within a few hours of the experiment, and no separation of the urantum and plutonium was necessary.

Both of the counting techniques required samples to be removed from the glove box. When the RackBeta counter was used, $10 \mathrm{~mL}$ of ACS 1iquid scintillation fluid was added to scintillation vials, which were put in individual plastic bags and bagged into the glove box. A 10- $\mu \mathrm{L}$ sample was carefully pipetted into the scintillation fluid so that neither the glove nor any contaminated surface contacted the vial. The vials were then bagged out in a clean bag and checked for external contamination. If PERALS counting was to be used, a 15- $\mu \mathrm{L}$ sample was pipetted into a 1-dram vial in a plastic bag. The vials were bagged out and checked for external contamination. In a hood, a 5- $\mu \mathrm{L}$ sample was pipetted into $1 \mathrm{~mL}$ of PERALS $^{9}, 10$ scintillation fluid for counting. 


\section{RESULTS AND DISCUSSION}

The experimental aspects of this study have focused, first, on the photochemical reduction of uranyl ion alone - to determine the optimum conditions for the $\mathrm{U}^{4+}$ generation process, and, second, on the photochemical reduction of uranyl ion in the presence of $\mathrm{Pu}^{4+}$ to demonstrate the practicality of the photoseparations process.

The development of a system for the photochemical reduction of $\mathrm{Pu}^{4+}$ to $\mathrm{Pu}^{3+}$ requires a reductant that is effective with respect to both quantum efficiency and kinetic speed. (The reason for separating these apparently redundant characteristics should become evident in the following discussion.) We have not found a reagent that satisfles these requirements directly since the photochemical reduction of $\mathrm{Pu}^{4+}$ is not very efficient; however, the dark reaction of $\mathrm{U}^{4+}$ with $\mathrm{Pu}^{4+}$ is so rapid and, thus, so attractive that a photochemical means of reducing $\mathrm{UO}_{2}{ }^{2+}$ could also provide a very satisfactory, indirect method for reducing $\mathrm{Pu}^{4+}$, as shown in Eqs. (1) and (2).

Although some of the uranyl photolysis work was presented earlier, 8 we have included an expanded version of it here (with additional discussion) to provide continuity with subsequent experiments where uranium and plutonium were combined in a two-phase flow system. Following the photolysis experiments with pure uranyl ion, tests were conducted using $\mathrm{UO}_{2}{ }^{2+} /-\mathrm{Pu}^{4+}$ mixtures to determine the efficacy of the overall photochemical scheme. 


\subsection{PHOTOLYSIS OF URANYL ION}

The quantum efficiencies given in Table 2 of ref. 8 indicate that a maximum value of 0.5 for conversion of $\mathrm{UO}_{2}{ }^{2+}$ to $\mathrm{U}^{4+}$ is feasible. Furthermore, we know 13 that the uranyl ion can be reduced with a variety of reductants by using light of relatively low photon energy (i.e., visible 1ight). Therefore, we sought to determine the best conditions for uranyl ion reduction, thereby providing $\mathrm{U}^{4+}$ which could be used to reduce $\mathrm{Pu}^{4+}$ in an appropriate demonstration facility. The reductants that were considered for $\mathrm{UO}_{2}{ }^{2+}$ were methanol, ethanol, $\mathrm{BuOH}$, hydroxylamine, and $\mathrm{N}_{2} \mathrm{H}_{4}$. The first two were selected because they are favorites in fundamental systems; the last three were chosen because they are possible constituents in fuel reprocessing streams.

The $\mathrm{UO}_{2}{ }^{2+}$ photolysis in $\mathrm{HNO}_{3}$ is very different from that in less oxfdizing media (e.g., $\mathrm{H}_{2} \mathrm{SO}_{4}$ since the $\mathrm{U}^{4+}$ in $\mathrm{HNO}_{3}$ is rapidly oxidized via the catalytic effect of the $\mathrm{NO}_{2}^{-}$that is almost always present in these solutions. (In contrast, the $\mathrm{U}^{4+}$ ion is so stable in $\mathrm{H}_{2} \mathrm{SO}_{4}$ solutions that the $\mathrm{UO}_{2}{ }^{2+}$ photolysis in $5 \underline{\mathrm{M}} \mathrm{H}_{2} \mathrm{SO}_{4}$ provides an excellent actinometer, as described in Sect. 2.4.) In order to stabilize the $\mathrm{U}^{4+}$ in $\mathrm{HNO}_{3}$ solution, it is necessary to add a holding reductant such as hydrazine, $\mathrm{N}_{2} \mathrm{H}_{4}$. Nevertheless, the stability of the $\mathrm{U}^{4+}$ ion is still far less than that in $\mathrm{H}_{2} \mathrm{SO}_{4}$ solutions. The results described in the following paragraphs will emphasize these differences.

We have considered the possibility that maintaining the $\mathrm{U}^{4+}$ stabi1ity during the actual reduction of $\mathrm{Pu}^{4+}$ might be unnecessary since $\mathrm{U}^{4+}$ may react before being reoxidized by any impurity ions; however, similar stability concerns exist with respect to $\mathrm{Pu}^{3+}$, and the stabilizing agent 
that is added for $\mathrm{Pu}^{3+}$ would probably also be useful for $\mathrm{U}^{4+}$. During the development of a procedure, we attempted to minimize the amounts of reductant and holding agents necessary and to obtain the maximum conversions and rates for a given light input (which was found to be $\sim 0.7 \mathrm{~W}$ of absorbed power). The acid concentration was fixed at $1 \underline{\mathrm{M}} \mathrm{HNO}_{3}$ to be consistent with conditions as stated for the first priority in Table 4 of ref. 8. The results of some of these experiments are summarized in Table 1 .

The data demonstrate that $\mathrm{BuOH}$ is the most effective of the reducing agents tested. Hydrazine was approximately ten times less effective, while hydroxylamine nitrate (HAN) was found to be totally ineffective. Butano1 was even more effective than a comparable concentration of ethanol. Because tributyl phosphate (TBP) has been demonstrated ${ }^{7}$ to be a reductant for $\mathrm{UO}_{2}{ }^{2+}$, an aqueous nitric acid solution saturated with TBP was tested. (Saturation was achieved by shaking with $30 \%$ TBP in n- $^{-}$ dodecane to achieve the approximate $1 \mathrm{mM}$ TBP concentration in the aqueous phase.) We found that under these conditions the TBP was ineffective in reducing any of the $\mathrm{UO}_{2}{ }^{2+}$ present. In all cases, the $\mathrm{U}^{4+}$ product was unstable unless $\mathrm{N}_{2} \mathrm{H}_{4}$ was present. (Consideration of other holding agents was beyond the scope of this work.) A concentration of $0.01 \underline{\mathrm{M}} \mathrm{N}_{2} \mathrm{H}_{4}$ was required to hold the $\mathrm{U}^{4+}$ for a period of several hours, whereas $0.001 \mathrm{M}$ $\mathrm{N}_{2} \mathrm{H}_{4}$ was effective for only a few minutes.

These results suggest that optimal conditions for the photochemical reduction of $\mathrm{UO}_{2}{ }^{2+}$ would include $0.01 \underline{\mathrm{M}} \mathrm{BuOH} / 0.01 \mathrm{M} \mathrm{N}_{2} \mathrm{H}_{4}$ and would result in a $\mathrm{U}^{4+}$ production rate of $4 \times 10^{-6} \mathrm{~mol} / \mathrm{min}$. In our particular system of $0.015-\mathrm{L}$ volume, this would net $11 \mathrm{mM} \mathrm{U}^{4+}$ after $48 \mathrm{~min}$ of photolysis an amount we consider adequate to reduce any $\mathrm{Pu}^{4+}$ that might be present. 
Table 1. Photochemical reduction of $1.25 \mathrm{M}$ uranyl nitrate in $1 \mathrm{M} \mathrm{HNO}_{3}$ using $\sim 0.7 \mathrm{~W}$ of absorbed power from a $1000^{-\mathrm{W}}, \mathrm{Hg}-\mathrm{Xe}$, high-pressure arc lamp ${ }^{\mathrm{a}}$

\begin{tabular}{|c|c|c|c|c|c|}
\hline \multirow{2}{*}{$\begin{array}{l}\text { Run } \\
\text { No. }\end{array}$} & \multirow[b]{2}{*}{ Reductant } & \multirow{2}{*}{$\begin{array}{c}\text { Photolysis } \\
\text { time } \\
\text { (min) }\end{array}$} & \multicolumn{3}{|c|}{ U(IV) production } \\
\hline & & & $\begin{array}{l}\text { Max. } \\
\left(10^{-3}\right.\end{array}$ & $\begin{array}{l}\text { conc. } \\
\mathrm{mol} / \mathrm{L})\end{array}$ & 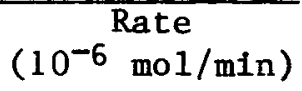 \\
\hline 33 & $1 \underline{\mathrm{M}} \mathrm{N}_{2} \mathrm{H}_{4}$ & 60 & & 33 & 9.5 \\
\hline 34 & $0.1 \underline{\mathrm{M}} \mathrm{N}_{2} \mathrm{H}_{4}$ & 120 & & 27 & 3.6 \\
\hline 35 & $0.01 \underline{\mathrm{M}} \mathrm{N}_{2} \mathrm{H}_{4}$ & 60 & & 1.4 & 0.37 \\
\hline 36 & $0.1 \underline{\mathrm{M}} \mathrm{HAN}$ & 40 & & 0 & 0 \\
\hline 37 & $0.05 \mathrm{M}$ HAN/0.05 $\mathrm{M} \mathrm{N}_{2} \mathrm{H}_{4}$ & 120 & & 10 & 1.3 \\
\hline 39 & $0.1 \mathrm{M} \mathrm{BuOH}$ & 60 & & 6.4 & 1.5 \\
\hline 40 & $0.1 \underline{\mathrm{M}} \mathrm{BuOH} / 0.01 \underline{\mathrm{M}} \mathrm{N}_{2} \mathrm{H}_{4}$ & 9 & & 26 & 43 \\
\hline 41 & $0.01 \underline{\mathrm{M}} \mathrm{BuOH} / 0.01$ M $\mathrm{N}_{2} \mathrm{H}_{4}$ & 48 & & 11 & 4.0 \\
\hline 43 & $0.01 \underline{\mathrm{M}} \mathrm{BuOH} / 0.001 \underline{\mathrm{M}} \mathrm{N}_{2} \mathrm{H}_{4}$ & 40 & & 9.4 & 4.1 \\
\hline 44 & $0.01 \underline{\mathrm{M} \mathrm{BuOH} / 0.005} \underline{\mathrm{M}} \mathrm{N}_{2} \mathrm{H}_{4}$ & 54 & & 9.4 & 4.2 \\
\hline 46 & $0.01 \mathrm{M} \mathrm{BuOH} / 0.0001 \mathrm{M} \mathrm{N_{2 } \mathrm { H } _ { 4 }}$ & 36 & & 9.6 & 4.1 \\
\hline 47 & $0.01 \underline{\mathrm{M}}$ EtOH/O.01 $\underline{\mathrm{M}} \mathrm{N}_{2} \mathrm{H}_{4}$ & 56 & & 7.5 & 2.4 \\
\hline 50 & $0.001 \mathrm{M}$ TBP & 20 & & 0 & 0 \\
\hline
\end{tabular}

aThe radiation was filtered to achieve a cutoff of all wavelengths below $350 \mathrm{~nm}$. The volume of the photochemical cell was $15 \mathrm{~mL}$. 
The maximum quantum efficiency (determined by the slope of the $\mathrm{U}^{4+}$ growth curve divided by the rate of light input) for $\mathrm{U}^{4+}$ using $0.01 \mathrm{M}$ $\mathrm{BuOH} / 0.01 \mathrm{M} \mathrm{N}_{2} \mathrm{H}_{4}$ is 0.050 . We find this to be an unusually low value since the theoretical value of 0.5 is easily achieved in the $\mathrm{H}_{2} \mathrm{SO}_{4}$ solutions. Even though the molar absorptivity of the $\mathrm{U}^{4+}$ is comparable to that of $\mathrm{UO}_{2}{ }^{2+}$ in the $400-$ to $450-\mathrm{nm}$ region (see Fig. 4), the small amount $(<1 \%)$ of $\mathrm{U}^{4+}$ formed ensures that most of the photochemistry effected by these photons is with $\mathrm{UO}_{2}{ }^{2+}$. Photoinduced oxidation of $\mathrm{U}^{4+}$ may occur as a result of light absorption at longer wavelengths (>500 nm) and, thus, be responsible for the apparently lower $\mathrm{QY}$ for $\mathrm{UO}_{2}{ }^{2+}$ reduction that we observe. However, we are unaware of any such photoactivity of $\mathrm{U}^{4+}$ in this region where the energy of the photon is considerably lower. If the low value is indeed correct, then it indicates potential limitations in the nitric acid system. (Surprisingly, these limitations did not prove to be a problem. The reasons for this are discussed in the following section, which deals with the photolysis of the combined $\mathrm{UO}_{2}{ }^{2+} / \mathrm{Pu}^{4+}$ system.)

\subsection{URANIUM/PLUTONIUM PHOTOLYSIS}

Having determined that the combination of $0.01 \underline{\mathrm{M}} \mathrm{BuOH}$ and $0.01 \mathrm{M}$ $\mathrm{N}_{2} \mathrm{H}_{4}$ was the most satisfactory of the reductants tested, we sought to combine these two reagents in a system containing both $\mathrm{UO}_{2}{ }^{2+}$ and $\mathrm{Pu}^{4+}$. Although the SRP flowsheet specifications describe a stage with $1.3 \mathrm{M}$ $\mathrm{UO}_{2}{ }^{2+}$ and $10^{-7} \underline{\mathrm{M}} \mathrm{Pu}^{4+}$ in $1 \mathrm{M}^{-} \mathrm{HNO}_{3}$, we chose a system that contained $1.0 \mathrm{M}$ $\mathrm{UO}_{2}{ }^{2+}$ and $4 \times 10^{-3} \mathrm{MPu}^{4+}$ in $1 \mathrm{MHN}_{3}$ for the initial tests. The choice was motivated by the realization that the higher concentration of $\mathrm{Pu}^{4+}$ would be easy to monitor spectrophotometrically and that, if the $\mathrm{U}^{4+}$ 
reductant generated was sufficient to reduce all of the $4 \times 10^{-3} \mathrm{M} \mathrm{Pu}^{4+}$, it would probably be sufficient to handle the lower concentrations.

In the first test of the mixed $\mathrm{UO}_{2}{ }^{2+} / \mathrm{Pu}^{4+}$ system, we merely added $\mathrm{Pu}^{4+}$ to the already established $\mathrm{UO}_{2}{ }^{2+}$ reduction in the single-phase experiment. When the concentrations of the $\mathrm{BuOH}$ and $\mathrm{N}_{2} \mathrm{H}_{4}$ reductants were each $0.01 \underline{M}$, quantum efficiencies of 0.125 to 0.137 were obtained for the formation of the $\mathrm{Pu}^{3+}$ product; and all of the plutonium was apparent1y reduced to $\mathrm{Pu}^{3+}$, as indicated by a final spectrum of the mixture. However, this system did not test the feasibility of photolyzing an aqueous phase in contact with an organic extractant which had removed a large amount of the two actinides. For this reason, we found it necessary to run a two-phase experiment.

The results of the two-phase photolysis experiments, shown in Table 2, demonstrate that good separation of $\mathrm{Pu}^{3+}$ into the aqueous phase can be achieved through this photo-redox stripping procedure. The final distribution coefficients given in the last column support this general conclusion. The quantum efficiencies for $\mathrm{Pu}^{3+}$ production are actually secondary values, resulting from the photochemical reduction of uranyl ion followed by the reaction of the reduction products with $\mathrm{Pu}^{4+}$ to form $\mathrm{Pu}^{3+}$ (Note that the quantum efficiencies are generally higher than those for $\mathrm{U}^{4+}$ production, as given in Sect. 2). All of the experiments were performed with $1 \underline{\mathrm{M}} \mathrm{UO}_{2}{ }^{2+}$, and the majority of those shown were run with $4 \times 10^{-3} \underline{\mathrm{M}}$ $\mathrm{Pu}^{4+}$ for the reasons stated earlier. Subsequently, the $\mathrm{Pu}^{4+}$ concentration was decreased gradually, by decades, until the detection limit of the PERALS scintillation counting technique was reached at $\sim 4 \times 10^{-6} \mathrm{M}$. 
Table 2. Summary of the two-phase experiments

Conditions: Circulation rate $=22 \mathrm{~mL} / \mathrm{min} ;\left[\mathrm{UO}_{2}\left(\mathrm{NO}_{3}\right) 2\right]=1 \mathrm{M}$; $\left[\mathrm{HNO}_{3}\right]=1 \mathrm{M}$; temperature $=25^{\circ} \mathrm{C}$ unless otherwise noted

\begin{tabular}{|c|c|c|c|c|c|c|c|c|}
\hline \multirow{2}{*}{$\begin{array}{l}\text { Run } \\
\text { No. }\end{array}$} & \multicolumn{4}{|c|}{ Concentration (M) } & \multirow{2}{*}{$\begin{array}{l}\text { Volume, } \\
\text { org/aq } \\
\text { (mL) }\end{array}$} & \multirow[b]{2}{*}{ QY } & \multirow[b]{2}{*}{ Methodc } & \multirow{2}{*}{$\begin{array}{c}\text { Final } \\
\mathrm{D}_{\mathrm{o} / \mathrm{a}}(\mathrm{Pu})\end{array}$} \\
\hline & & $\mathrm{Pu}^{\mathrm{a}}$ & $\mathrm{Pu}{ }^{\mathrm{b}}$ & $\mathrm{N}_{2} \mathrm{H}_{4} / \mathrm{BuOH}$ & & & & \\
\hline 60 & 4 & $\times 10^{-3}$ & $3.97 \times 10^{-3}$ & $0.01 / 0.01$ & $35 / 35$ & 0.137 & S & \\
\hline 62 & 4 & $\times 10^{-3}$ & $3.84 \times 10^{-3}$ & $0.001 / 0.001$ & $35 / 35$ & 0.054 & $s$ & \\
\hline 63 & 4 & $\times 10^{-3}$ & $3.97 \times 10^{-3}$ & $0.001 / 0.001$ & $35 / 35$ & 0.068 & $S, P$ & \\
\hline $67 d$ & 4 & $\times 10^{-3}$ & $2.60 \times 10^{-3}$ & $0.001 / 0.001$ & $35 / 35$ & 0.076 & $\mathrm{~S}$ & \\
\hline $67^{d}$ & 4 & $\times 10^{-3}$ & $4.0 \times 10^{-3}$ & $0.01 / 0.01$ & $35 / 35$ & 0.114 & S & \\
\hline 73 & 4 & $\times 10^{-3}$ & $3.4 \times 10^{-3}$ & $0.01 / 0.01$ & $180 / 45$ & 0.093 & $\mathrm{~S}$ & \\
\hline $72^{e}$ & 4 & $\times 10^{-3}$ & $2.6 \times 10^{-3}$ & $0.01 / 0.01$ & $180 / 45$ & 0.049 & $\mathrm{~S}$ & \\
\hline $82^{f}$ & 4 & $\times 10^{-3}$ & $2.8 \times 10^{-3}$ & $0.01 / 0.01$ & $180 / 45$ & 0.121 & $\mathrm{~S}$ & \\
\hline $70^{g}$ & 4 & $\times 10^{-3}$ & n.a. & $0.01 / 0.01$ & $180 / 40$ & 0.080 & $\mathrm{~s}$ & \\
\hline 64 & 4 & $\times 10^{-4}$ & $3.8 \times 10^{-4}$ & $0.001 / 0.001$ & $35 / 35$ & & $S, P$ & 0.050 \\
\hline 69 & 4 & $\times 10^{-4}$ & $3.5 \times 10^{-4}$ & $0.001 / 0.001$ & $180 / 45$ & & $\mathrm{P}$ & 0.037 \\
\hline 65 & 4 & $\times 10^{-5}$ & $3.9 \times 10^{-5}$ & $0.001 / 0.001$ & $35 / 35$ & & $\mathrm{P}$ & 0.025 \\
\hline 74 & 4 & $\times 10^{-5}$ & $3.9 \times 10^{-5}$ & $0.01 / 0.01$ & $180 / 45$ & & $\mathrm{P}$ & 0.006 \\
\hline 76 & 4 & $\times 10^{-6}$ & $3.7 \times 10^{-6}$ & $0.01 / 0.01$ & $180 / 45$ & & $\mathbf{P}$ & 0.02 \\
\hline 77 & 4 & $\times 10^{-6}$ & $3.7 \times 10^{-6}$ & $0.01 / 0.01$ & $180 / 45$ & & $P$ & 0.018 \\
\hline
\end{tabular}

a Pul originally present in aqueous phase prior to extraction.

b[Pu] final in aqueous phase after photoreductive stripping from the organic phase.

Method: $S=$ spectrophotometric; $P$ = PERALS.

dExperiment run at $50^{\circ} \mathrm{C}$.

experiment run at $45^{\circ} \mathrm{C}$.

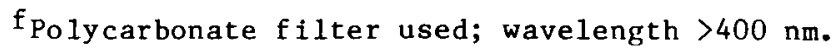

$\mathrm{g}_{\text {Methanol used in place of butanol. }}$

n.a. = not avallable; however, total reduction to $\mathrm{Pu}^{3+}$ was apparent. 
Most of the experiments were performed with $0.01 \mathrm{M}$ of each reductant; however, a few were performed with $0.001 \mathrm{M}$ to test the possibility of using smaller amounts of the reductants. As stated earlier, BuOH was selected because it is a product of TBP degradation and therefore would not necessarily be foreign to the system. Nevertheless, other reductants could function almost as well as shown by the data for methanol in experiment 70 .

The noticeable drop in quantum efficiency with decreased reductant concentration should be noted. These values were determined from the slopes of the $\mathrm{Pu}^{3+}$ growth curves for continuous illumination and not from the ultimate values reached for a limited exposure (see Sect. 2). The slower growth of $\mathrm{Pu}^{3+}$ was probably caused by the mixing speeds since the reaction of $\mathrm{U}^{4+}$ is known to be rapid; therefore, these decreases in quantum efficiencies represent only the variations in reaction rates due to differences in the steady-state concentrations. Quantum efficiencies were not observed for the lower $\mathrm{Pu}^{4+}$ concentrations because, if sufficient reductant was present to reduce the $4 \times 10^{-3} \mathrm{M} \mathrm{Pu}^{4+}$ solution, there would obviously be an excess for the lower $\mathrm{Pu}^{4+}$ concentrations.

Some of the experiments were conducted with equal amounts of organic and aqueous phases (i.e., the $35 / 35-\mathrm{mL}$ volume ratios). Under such conditions, the organic phase was saturated with uranyl nitrate, attaining a maximum concentration of $0.5 \mathrm{M}$ and leaving an equivalent amount of uranyl ion in the aqueous solution. However, because the SRP process conditions include a 5:1 organic/aqueous (o/a) volume ratio, we sought to approach these conditions with an increase in the amount of organic phase. The larger organic contactor cell described in sect. 2 was used to run some 
experiments with $5: 1,4.5: 1$, and $4: 1$ volume ratios. The contactor could not accommodate the 5:1 ratio satisfactorily because some of the organic phase was driven into the spectrophotometric cell compartment by the pumping operation, thus interfering with the measurement of the spectra. The o/a ratio was successively reduced until the aqueous solution could be circulated with no interference of organic in the optical path. The best results were obtained at the 4:1 ratio, but data from some of the earlier runs at the 4.5:1 ratio have also been included.

The higher o/a ratio system produced more complete extraction of the $\mathrm{UO}_{2}{ }^{2+}$, leaving only $0.045 \mathrm{M}$ in the aqueous with a final distribution coefficient $\mathrm{D}_{\mathrm{o} / \mathrm{a}}\left(\mathrm{UO}_{2}{ }^{2+}\right)=5.3$ for the the $4: 1$ ratio. Under these conditions, the amount of light absorbed during photolysis was less because of the short pathlength of the photolysis chamber and the dilute uranyl nitrate solution. Since less light was being absorbed by the system, the steady-state concentration of the uranium reductant (mainly $\mathrm{U}^{4+}$ ) was lower; thus, the measured quantum yield appears to be lower. However, an advantage of the dilute solution is that the generation of $\mathrm{U}^{4+}$ would be more uniform along the pathlength of the exciting light than in the corresponding solution containing $1 \underline{\mathrm{M} \mathrm{UO}_{2}}{ }^{2+}$, where most of the 1 ight absorption occurs in the first few millimeters of solution.

The effect of temperature on the photolysis was also examined at $\left[\mathrm{Pu}^{4+}\right]=4 \times 10^{-3} \underline{\mathrm{M}}$. Solutions with o/a ratios of $1: 1$ and $4: 1$ were examined at 50 and $45^{\circ} \mathrm{C}$, respectively. The quantum efficiency appears to decrease from 0.137 (at $20^{\circ} \mathrm{C}$ ) to 0.115 (at $50^{\circ} \mathrm{C}$ ) for $1: 1$ solutions and from $0.093\left(\right.$ at $20^{\circ} \mathrm{C}$ ) to 0.049 (at $45^{\circ} \mathrm{C}$ ) for the $4: 1$ solutions. Most of this decrease is attributed to an increase in the rate of $\mathrm{Pu}^{3+}$ oxidation that we observed at the higher temperatures. 
Distribution coefficlents of $\mathrm{Pu}^{4+}$ and $\mathrm{UO}_{2}{ }^{2+}$ were measured prior to photolysis and were found to be $0.41 \pm 0.3$ and $5.3 \pm 0.8$, respectively,

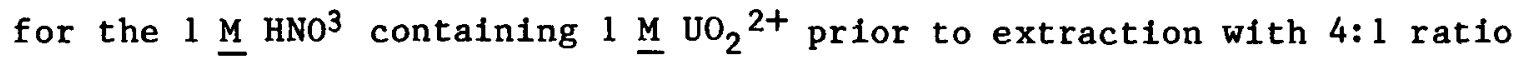
organic that had been pre-equilibrated with acid beforehand. These values agree favorably with those given earlier.14,15 It should be noted that the low acid value and the high $\mathrm{UO}_{2}{ }^{2+}$ content cause the $\mathrm{Pu}^{4+}$ to favor the aqueous phase; hence, the effects of photochemical reduction and subsequent stripping are not as dramatic. Nevertheless, the final distribution coefficient for plutonium (as shown in the experiments where the counting techniques were employed) has been reduced by at least a factor of 10 to a value which is consistent with that predicted for $\mathrm{Pu}^{3+} .16$ The range of distribution coefficient values in the last column of Table 2 is probably the result of incomplete equilibration in the solutions.

The final concentration of plutonium in the aqueous phase was found to be at least $87.5 \%$ (determined from columns two and three of the table) that of the starting value in all cases except those where the higher temperatures or the polycarbonate filter were used (see Table 2, columns 2 and 3). As stated earlier, the higher temperatures caused some loss in $\mathrm{Pu}^{3+}$ stability and, in turn, the lower quantum efficiencies. The decreased stability of the $\mathrm{Pu}^{3+}$ is not believed to be a function of the photochemical process; instead, it appears to be related to the nature of the system (i.e., oxidation by $\mathrm{NO}_{\mathrm{x}}$ species) and should not reflect on the merits of the photochemical method.

We sought to evaluate the efficacy of using longer-wavelength radiation in the uranium photoreductive stripping of plutonium, since photodegradation of the solvent is of concern. (However, no solvent degradation was observed for any of the experiments described in this report.) 
The effect of the polycarbonate filter, which excluded all light of wavelengths shorter than $400 \mathrm{~nm}$, was seen in the amount of $\mathrm{Pu}^{3+}$ product formed. It appears that the longer-wavelength light is not satisfactory for complete reduction of $\mathrm{Pu}^{4+}$; however, we have no explanation for this observation, because our actinometry measurements demonstrate that no less than half of the original number of photons (i.e., those which were passed by the $350-\mathrm{nm}$ cutoff filter) are still being absorbed, and this number should be sufficient for eventual reduction of all the $\mathrm{Pu}^{4+}$. We have also considered the possible reflux oxidation of the $\mathrm{Pu}^{3+}$ that has been identified in the $\mathrm{U}^{4+} / \mathrm{Pu}^{4+}$ reduction process.17 This procedure was tested in the experiment with $4 \times 10^{-6} \mathrm{M} \mathrm{Pu}^{4+}$ where pheny1hydrazine was added in place of the $\mathrm{H}_{2} \mathrm{~N}_{4}$, anticipating that its greater solubility in the organic phase would eliminate any back-oxidation of $\mathrm{Pu}^{3+}$ occurring there. No significant difference was achieved with this reductant to warrant the conclusion that these experiments were being limited by this phenomenon.

Figures 5 through 8 summarize some of these results in a manner that includes the effect of time on the concentration of plutonium in the organic phase as $\mathrm{Pu}^{4+}$ is being reductively stripped into the aqueous phase. It should be stressed that the methods of circulation and mixing were very rudimentary by reprocessing standards; therefore, the 20-min rates are a function of the mixing system. Figure 5 gives the results for the $4 \times 10^{-3} \underline{M}$ plutonium reductive stripping. The horizontal line at the top of the figure is the $\mathrm{Pu}^{4+}$ concentration in the aqueous phase prior to extraction; the $\left[\mathrm{Pu}^{4+}\right]$ at $\mathrm{t}=0$ is the equilibrium value of the $\mathrm{Pu}^{4+}$ after extraction. The two lines are for the same experiment: the line 
ORNL DWG 86-106

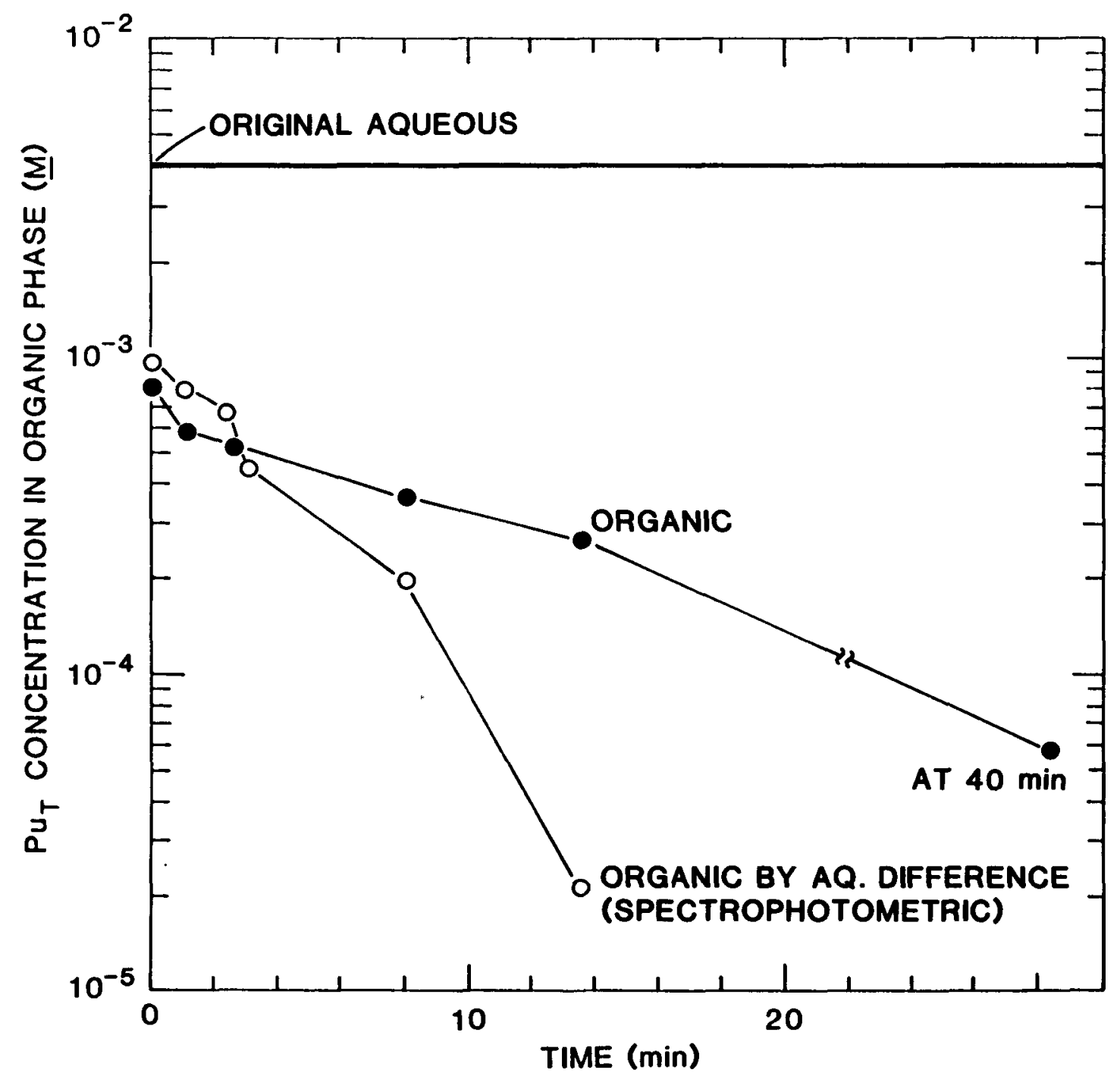

Fig. 5. Change in the [Pu] as a function of photolysis time in the two-phase extraction system for $4 \times 10^{-3} \underline{M}$ total plutonium. 
ORNL DWG 86-105

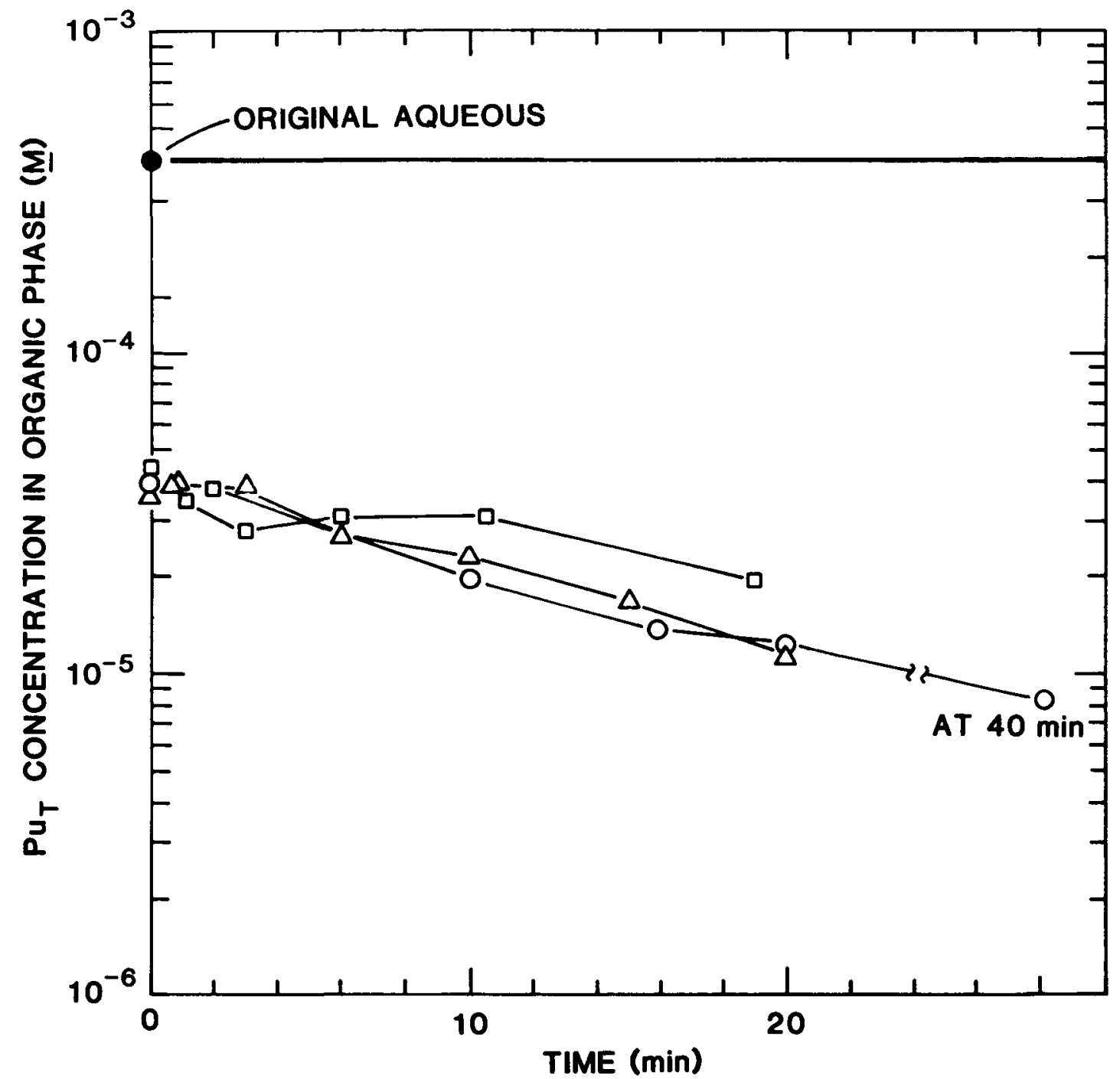

Fig. 6. Change in the [Pu] as a function of photolysis time in the two-phase extraction system for $4 \times 10^{-4} \underline{M}$ total plutonium. 
ORNL DWG 86-107

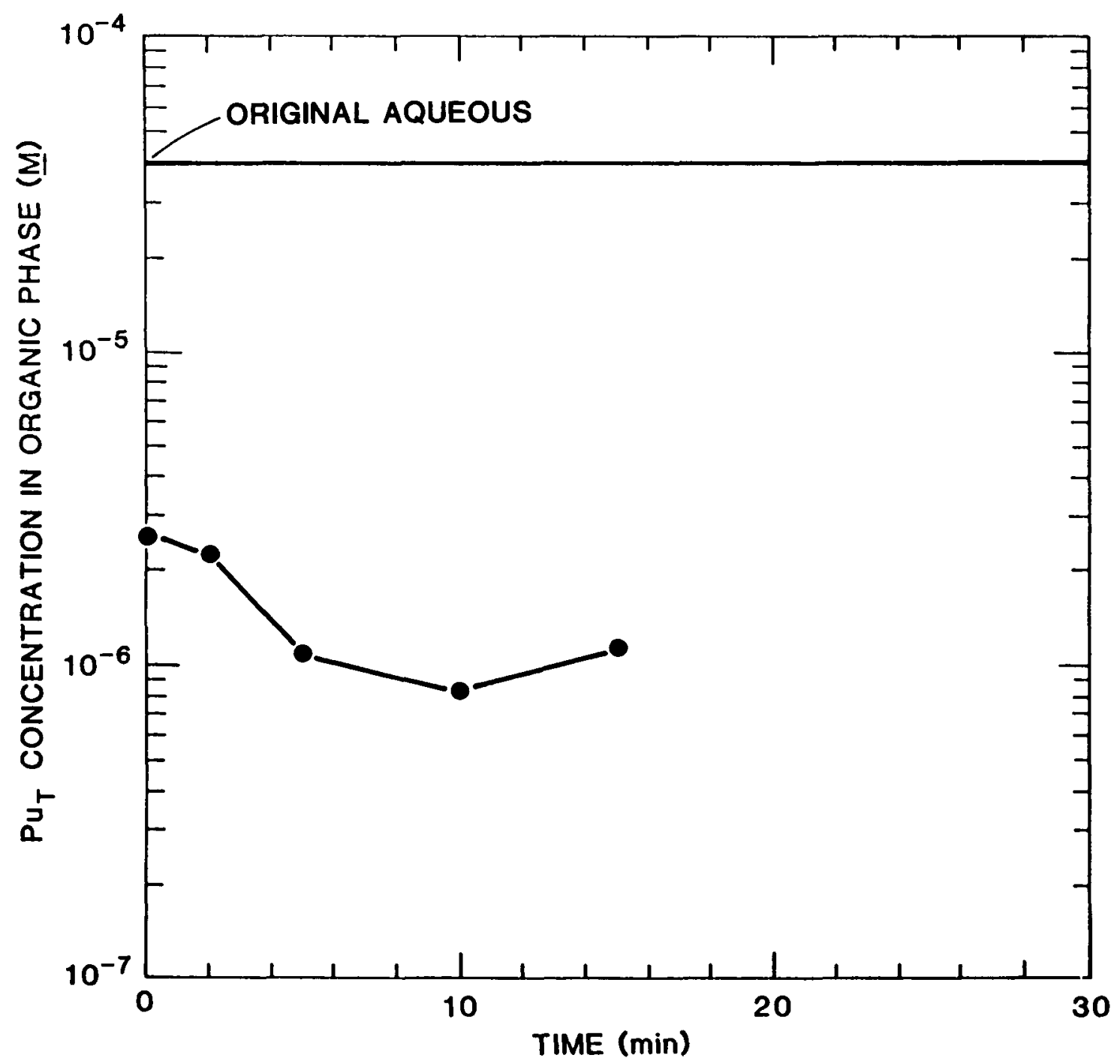

Fig. 7. Change in the [Pu] as a function of photolysis time in the two-phase extraction system for $4 \times 10^{-5} \underline{M}$ total plutonium. 
ORNL DWG 86-108

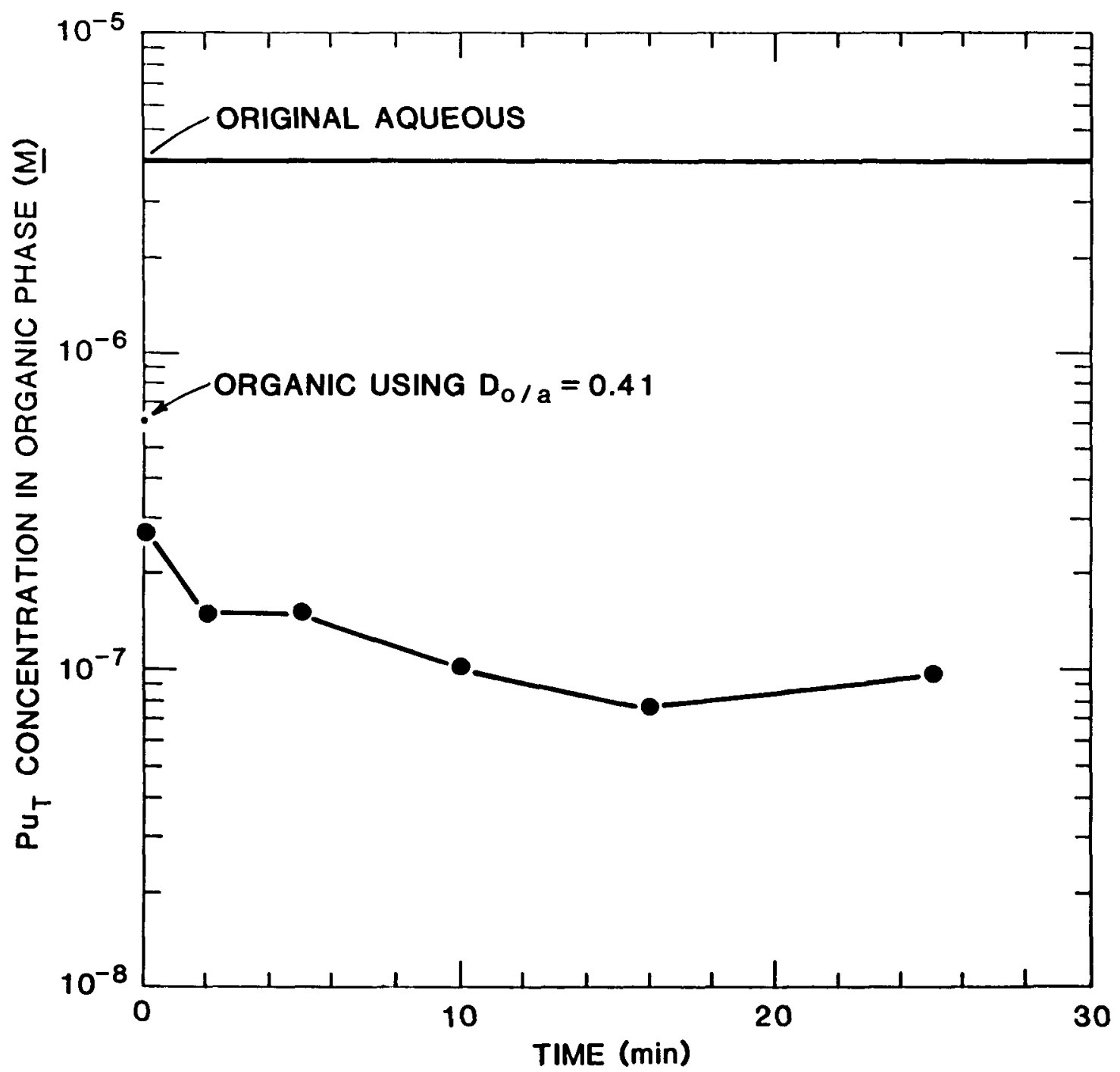

Fig. 8. Change in the [Pu] as a function of photolysis time in the two-phase extraction system for $4 \times 10^{-6} \mathrm{M}$ total plutonium. 
marked "organic" represents values determined by counting techniques; the line marked "spectrophotometric difference" represents values determined by subtracting the concentration found in the aqueous by absorption spectrophotometry from the total concentration. The great divergence of the two lines is due to the error involved in the spectrophotometric measurement at the end of the photolysis - the difference between this measured $\mathrm{Pu}^{3+}$ and the starting concentration is a small number with considerable error.

In considering the same type of plot for $4 \times 10^{-4} \underline{M}$ (Fig. 6), $4 \times 10^{-5}$ $\underline{M}$ (Fig. 7), and $4 \times 10^{-6}$ M plutonium (Fig. 8), we see similar basic trends. In fact, these figures could be superimposed on each other if the differences in the $\left[\mathrm{Pu}_{\mathrm{T}}\right]$ were ignored. The $\left[\mathrm{Pu}^{4+}\right]$ starts at a value, when $t=0$, which is representative of the distribution coefficient for $\mathrm{Pu}^{4+}$. However, we cannot explain the apparent decrease in $\mathrm{D}_{0} / \mathrm{a}\left(\mathrm{Pu}^{4+}\right)$ as the concentration of plutonium decreases. The total plutonium concentration decreases at the same rate during the photolysis and to the same relative limits in all of the figures, reaching a limiting value equivalent to $-0.08 / 4.0$ of (as read from Figs. 5-8, 1.e., $2 \%$ ) the original value. This limiting value is indicative of a $\mathrm{Pu}^{3+}$ distribution coefficient, $D_{0} / a$, of 0.02 and is consistent with what is expected. 14

The fact that all of these curves almost overlay each other suggests that the rates are not being controlled by the chemistry of the reduction process, but, instead, by the rate of circulation and mixing (i.e., organic to aqueous transfer). If they were controlled by the chemistry, they would be progressively slower as the total [Pu] was decreased. These data are encouraging from the standpoint that the rate of separation by reductive stripping in the system tested here is controlled by 
the circulation and mixing - factors that would obviously be improved in a more sophisticated reprocessing system.

In support of the conclusions regarding mixing, the results of many of our early experiments gave data points that scattered so badly that the trends indicated in the figures were indiscernible. Observations of the circulating solution revealed that the organic phase was not being adequately agitated by the $22-\mathrm{mL} / \mathrm{min}$ stream emptying onto the top surface. Manual stirring prior to sampling dramatically decreased the scatter of points.

The apparent anomaly in the low quantum efficiency for $\mathrm{U}^{4+}$ production and the much higher "secondary" values for $\mathrm{Pu}^{3+}$ production were of considerable concern since they implied that another reductant besides the $\mathrm{U}^{4+}$ was being generated. Realizing the stoichiometry of Eq. (2), we can explain the discrepancy if the values differed by a factor of 2 ; however, we found that they differ by a factor of 2.5 , suggesting the presence of some remaining $\mathrm{UO}_{2}{ }^{+}$[i.e., $\left.\mathrm{U}(\mathrm{V})\right]$ to account for the additional reduction of $\mathrm{Pu}^{4+}$. The intermediate $\mathrm{UO}_{2}{ }^{+}$is probably an even more effective reductant than $\mathrm{U}^{4+}$ (since an electron is transferred without molecular rearrangement). Nevertheless, the relatively high quantum efficiencies for $\mathrm{Pu}^{3+}$ generation satisfy the needs that we are addressing.

\section{CONCLUSIONS}

The reduction of $\mathrm{Pu}^{4+}$ using photochemically generated $\mathrm{U}^{4+}$ has been shown to be an efficient process, reaching "secondary" quantum efficiencies as high as 0.137 by using the reductant combination of $0.01 \mathrm{M} \mathrm{BuOH}$ 
and $\mathrm{N}_{2} \mathrm{H}_{4}$ - Concentrations of $\mathrm{Pu}^{4+}$ as low as $4 \times 10^{-6} \underline{\mathrm{M}}$ have been successfully stripped from a TBP/n-dodecane phase with no apparent loss of efficiency. We can then infer that still lower concentrations could be separated with comparable efficiency. The only limiting factor in our testing procedure was the simple method used for stirring and mixing. With improved mixing, a faster rate of reductive separation could be expected.

No degradation of the organic phase was observed as a result of the photolysis with wavelengths $>350 \mathrm{~nm}$. Therefore, the use of light with a wavelength $>400 \mathrm{~nm}$ would be of no significant advantage. The photoreduction was shown to proceed successfully at higher temperatures; the only limitation was a decreased stability of the $\mathrm{Pu}^{3+}$ produced. Although the experiments performed in this study focused on the $\mathrm{BuOH} / \mathrm{N}_{2} \mathrm{H}_{4}$ reductant combination, a number of other reductants could be used, if some means of stabilizing the $\mathrm{Pu}^{3+}$ were provided.

\section{REFERENCES}

1. J. T. Bell and H. A. Friedman, J. Inorg. Nucl. Chem. 38, 831 (1976).

2. H. A. Friedman, L. M. Toth, and J. T. Be11, J. Inorg. Nucl. Chem. 39, 123 (1977).

3. H. A. Frledman, L. M. Toth, and M. M. Osborne, J. Inorg. Nuc1. Chem. 41, 1339 (1979).

4. L. M. Toth and H. A. Friedman, Radiochim. Acta 27, 173 (1980).

5. H. A. Friedman, L. M. Toth, and J. T. Be11, "Method for Selectively Reducing Plutonium Values by a Photochemical Process," U.S. Patent $4,131,527$ (1978). 
6. H. A. Friedman and L. M. Toth, "Method for Selectively Reducing Neptunium Values by a Photochemical Process," U.S. Patent application, May 12, 1983.

7. G. L. DePoorter and C. K. Rofer-DePoorter, "Method for Photochemical Reduction of Urany1 Nitrate by TBP and Application of This Method to Nuclear Fuel Reprocessing," U.S. Patent 4,080,273.

8. L. M. Toth, J. T. Be11, J. C. Mailen, and K. E. Dodson, An Assessment of Photochemical Applications to Specific Stages in Savannah River Plant Actinide Reprocessing Streams, ORNL/TM-9755, Oak Ridge National Laboratory, December 1985.

9. W. J. McDowe11, Alpha Liquid Scintillation Counting: Past, Present, and Future, in Liquid Scintillation Counting, Recent Applications and Development, C. T. Peng, D. L. Horrocks, and E. L. Alpen, eds., Academic Press, New York, 1980.

10. W. J. McDowe1l, "Simple, Accurate Alpha Assay by Liquid Scintillation Methods," paper presented at the American Nuclear Society Meeting in San Francisco, Calif., Nov. 29-Dec. 5, 1981.

11. J. T. Bel1 and M. R. Billings, J. Inorg. Nucl. Chem., 37, 2529 (1975).

12. D. T. Bostick and J. E. Strain, The Electroreduction and Photometric Detection of Low-Level Uranium in Aqueous Purex Solutions, ORNL/TM-8646, Oak Ridge National Laboratory, April 1983.

13. J. T. Be11 and L. M. Toth, Radiochim. Acta 25, 225 (1978).

14. 0. J. Wick, Plutonium Handbook, Vo1. 1, American Nuclear Society, Lagrange Park, I11inois, 1980. 
15. J. B. Knauer, M. H. Lloyd, and J. T. Barker, Plutonium, Uranium, and Thorium Distribution Coefficients in the 30 vol \% TBP-NDD-Nitric Acid System at 25 and $50^{\circ} \mathrm{C}$, ORNL/TM-7804, Oak Ridge National Laboratory, April 1982 .

16. W. D. Bond, private communication, Oak Ridge National Laboratory, 1985.

17. P. Biddle, H. A. C. McKay, and J. H. Miles, "The Role of Nitrous Acid in the Reduction of Plutonium(IV) by Uranium(IV) in TBP Systems," in H. A. C. McKay, T. V. Healy, I. L. Jenkins, A. Naylor, eds., Solvent Extraction Chemistry of Metals, MacMillan, London, 1965, p. 133. 
ORNL/TM- 9958

INTERNAL DISTRIBUTION

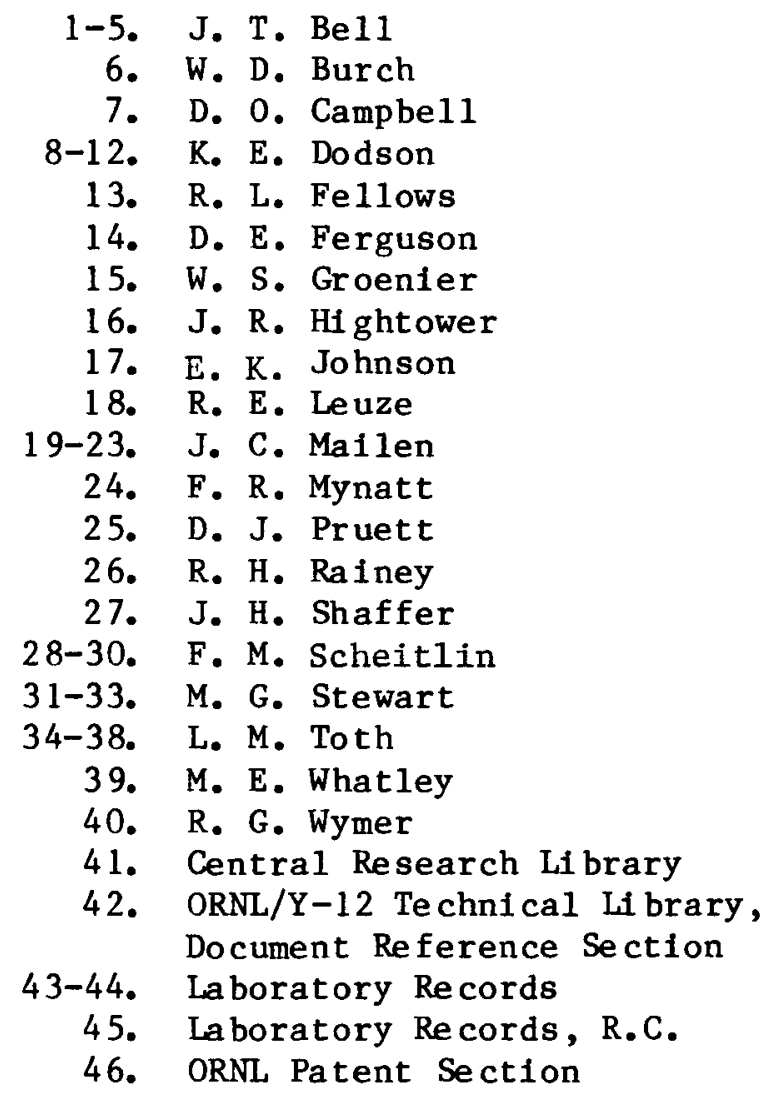

EXTERNAL DISTRIBUTION

47-51. S. T. Augsberger, Savannah River Laboratory, Aiken, SC 29808-0001

52. H. D. Ha rmon, Sa vannah River Laboratory, Aiken, SC 29808-0001

53. R. T. Walters, Savannah River Laboratory, Aiken, SC 29808-0001

54. Office of Assistant Manager for Energy Research and Development, DOE-ORO, P.O. Box E, Oak Ridge, TN 37831

55-56. Technical Information Center, Oak Ridge, TN 37830 